\title{
CHINA'S FOREIGN POLICY AFTER THE COLLAPSE OF THE USSR: CHANGES, CHALLENGES AND OPPORTUNITIES
}

\author{
Guudain Tumurchuluun
}

\section{Introduction}

China has become a hot topic among business and foreign policy elites in neighboring countries but has also become the main concern of the United States and Europe. China's rise, many researchers predict, may be the most important trend in the world for the next century. China is the fastest growing economy with the fastest growing military budget in the world. With a population of 1.2 billion and nuclear weapons, it has border disputes with most of its neighbors The former Singaporean Prime Minister Lee Kuan Yew says: "The size of China's displacement of the world balance is such that the world must find a new balance in thirty to forty years. It's not possible to pretend that this is just another big player. This is the biggest player in the history of man"/I/

The task I have set for myself is this paper in to analyze China's domestic and international environment and constraints on its foreign policy, and to make some tentative forecasts.

\section{China's Domestic and International Environment}

\section{Economic policies}

When one looks at Chinese domestic policies, one quickly discovers that the paramount task pursued by the leadership is economic development. According to many experts, China is doing well in developing its economy and opening up to the outside world 111.

China's present economic boom started in about 1980 and since has resulted in real annual growth averaging $9 \%$. It has shown no signs of slowing down: in 1992 the GNP grew by $128 \%$ and in 1993, 13\%, raising concerns about an overheating of the economy. Some economists believe that with political stability and an open global trading system, China could rack up annual growth rates of $7-8 \%$ for at least another two decades. At $8 \%$ an economy quintuples in size every twenty-one years $/ 3 /$. Most important, annual increases in overall agrarian productivity have averaged $4 \%$, nearly double the pre- 1979 rates. The 
dynamism of newly encouraged rural small and medium-sized industries has been especially noteworthy and has greatly contributed to a rapidly rising rural income in many regions. By the beginning of 1990 problems of food and clothing for the 800 million farmers had been basically solved.

However, several crucial problems still remain unsolved, such as inefficient state-owned companies and archaic banking, financial, tax, trade, legal and accounting systems These older problems have been joined lately by problems caused by the transition from a planned to a market economy. The biggest problem is China's large population. With only $7 \%$ of all arable land China, with 1.2 billion people, accounts for $22 \%$ of the world's population, and it is likely to reach 1.5 billion in the early twenty-first century. Over the last few years the Chinese labor force is said to have increased by 175 million. To absorb this labor force will constitute a formidable challenge to China.

Another problem is the growing gap between the richer South and the more backward North. Provinces like Guangdong are developing much faster than, for example. Xinjiang or Inner Mongolia. These northern regions expect more assistance and subsidies from the central government, while the southern provinces want to have control over their own revenues. This leads us to the decentralization issue.

China has always been much less centralized than, say, the former USSR/ 4/ For centuries Beijing and the provinces have been arguing over the appropriate degree of central control, and the center has learned to accept the fact that it can-not control everything, and to permit a significant degree of autonomy. After Mao's death and the dissolution of the ideological glue which held the country together, the administration which had always been potentially more decentralized, became so in fact. Effective control by the center declined sharply, as many provinces raced to take advantage of new opportunities to pursue their own local development strategies, regardless of Beijing's wishes. Periodic efforts by Beijing to rein in the provinces have not been successful, and the country continues to further decentralize. This has led to increasing uncertainty over the exact nature of relations between Beijing and the provinces. As a result, demands are being heard for the codification of authority for each level of government in the country, with the hoped for result that the present chaotic and informal network of relations can be done with.

On the positive side, decentralization does not seem to have hindered economic development because throughout the 1980s China's economy grew at an average annual rate of almost $10 \%$. Also, decentralization and reform seem actually to have helped equalize levels of development among ethnically Chi- 
nese provinces. This is to say that inequalities have not disappeared. The gap in per capita output between Guangdong and Tibet has widened over the decade, as has the gap between Chinese provinces as a whole and those regions inhabited by minorities which, in turn, will strain Beijing's relations which them.

A third, and most worrisome, problem is the overheating of the economyFears first surfaced around the end of 1992, a year in which the economy grew by $12.8 \%$ and inflation began to take off. As 1993 got underway, there were no signs of a slowdown. In the first half of the year investment in fixed assets soared by about $60 \%$, compared with the same period in 1992, and industrial output rocketed by about $30 \%$.

In June, with inflation topping 25\% in China's major cities. Vice-Premier Zhu Rongzi unveiled a 16-point plan to get to the root of the problem. His measures had some effect as money growth slowed slightly in the second half of the year, property prices cooled and more than 1,000 so-called development zones were closed. But Zhu was unable to complete his program, partly because of resistance from provinces and orders from above. As a result, the Chinese economy had another sizzling year in 1993 growing by about 13\%. With industrial output rising by almost $20 \%$. This year, the Chinese may face the same problem, as industrial output in January was up 33\% over the same month in 1993/5/. Inflation hovered around 20\% in China's thirty-five major cities. In midDecember 1993, expectations of tax increases in 1994 led to panic buying and hoarding. The result was a $40 \%$ increase in food prices in a single week, prompting the government to impose price controls on twenty-seven staples. Inflation also made an impact in rural areas where the farmers were often the victims of monetary mismanagement. Some profligate local governments started to levy illegal taxes, the most dramatic case occurring in Sichuan where farmers rioted in protest in June.

If we look at the prospects of the Chinese economy, one point seems inescapable, namely that economic reforms will continue. There is no turning back. In an interview with the Asian Wall Street Journal on December 10, 1993, Vice Premier Zhu said, "Now we are prepared to introduce the most unprecedented, significant and profound economic structural reforms in the history of China". These words have been confirmed by recent actions aimed at speeding up economic reforms. In early 1994 the government introduced a sweeping tax reform, including the imposition of a value-added tax. A consumption tax on luxury items, a turnover tax on services, a tax on land appreciation, and a real estate tax. Later this year the government will press on with overhauling China's 
banking system. The People's Bank of China will be given independent powers to conduct monetary policy and to supervise the financial system.

China's leadership cannot afford to ignore threats posed by inflation or signs of social unrest both in the countryside and in the cities, but there is little room to maneuver between political expediency and the need to maintain strict controls on monetary growth. Mr. Zlu; has shown that he is prepared to risk strong opposition to his austerity program, but he cannot be certain that he will prevail

\section{The Political Situation}

The current leadership sees a stable social order as its most important political task. In order to reach this goal, it will unswervingly take the road of "building socialism with Chinese characteristics". The leadership interprets this phrase to mean a close link between economic development and the "four cardinal principles'76/ which include the dictatorship of the Communist Party and strict adherence to "Marxism-Leninism and Mao Zedong Thought". Political pluralism would undermine the party's supremacy and split the nation. China's chosen route is different from the Western multiparty system which is deemed both unwise and unnecessary. The challenge from political pluralism is equated with inter-ference in China's internal affairs, thereby linking the defense of socialism with the defense of Chinas national integrity.

Domestic stability is challenged by four problems-leadership change, economic reforms, human rights, and ethnic relations-with leadership change being the most imminent. Soon the present leaders will be gone, and the ongoing debate within the leadership can then be expected to grow sharper. This debate is centered around the proper relationship between economic and political reforms, between "reformers or radicals on the one hand and conservatives or moderates on the other hand' $77 /$. The outcome of the struggle seems to depend directly on the success or failure of economic reforms

The reforms which began in 1979, have opened new possibilities for China, especially for the better educated people the achievements of neighboring markctoricnlcd economics became known, including the Chinese economies in Hong Kong. Singapore and Taiwan. At the same lime, they facilitated more open expressions of dissent which grew when Hu Yaobang and Zhao Ziyang led the Communist Party. Then, in 1989. Came Tiananmen. Many students were imprisoned, declared repenlent. And then released, although many are said to be still in prison/8/. Since Tiananmen, opportunities to criticize and study abroad were sharply curtailed Tens of thousands of Chinese students overseas expressed 
their unwillingness to return home, while in China new human-rights cases keep cropping up. As most recently the detention of Catholic missionaries.

Ethnic minorities account for only $8 \%$ of the population and live in widely separated areas Therefore, they cannot unite politically and thus pose no threat to the leadership. They may. However, undermine China's unity In Tibet the

Regime has encountered periodic public protests, especially by monks, in spite of formal military rule. Similarly, in Xinjiang there have been periodic protests by Uighurs and others over the suppression of their culture, the use of their region for nuclear testing, and restrictions placed on the practice of Islam. The regime has responded by closing a number of mosques, banning the construction of previously approved mosques, and closing a number of private schools some of which had been funded from the Middle East. Inner Mongolia has witnessed repeated unrest, jDartly as a result of the democratic revolution in Mongolia.

It is clear that the regime cannot afford to look upon ethnic unrest with complete equanimity. The minority areas cover about $60 \%$ of the national territory and are mostly situated along China's frontiers. Moreover, in Xinjiang, Inner Mongolia, Tibet, Yunnan, and to a lesser extent in the Northeast, the same ethnic groups live on both sides of the border and thus make Beijing more apprehensive about security than it would otherwise be.

\section{The International Environment}

China's international environment may be divided into two spheres, its neighbors and the new world balance of power.

China's neighbors may be grouped into four categories: major powers like Russia, India and Japan, the Indochinese countries and North Korea, Taiwan, and other nations. The collapse of the USSR has played a decisive role in the improvement of China's external environment, both in terms of its neighbors and the new world balance of power. The collapse meant, first of all, the end of a perceived Soviet encirclement, represented by the huge Soviet military presence in Afghanistan, along China's northern frontier, in Vietnam, and in India. This encirclement led Beijing to declare non-alignment, with a tilt toward Japan and the United States.

By the early 1980s relations began to improve, leading to Gorbachev to visit China in 1989 and Yeltsin in 1992. During Gorbachev's visit the two countries signed the Joint Declaration on Bilateral Relations which to a certain extent re-placed the once annulled Friendship Treaty of 1949. Over twenty additional agreements were signed during Yeltsin's visit. On January 28, 1993 China and 
Russia decided to open twenty-one border crossings, thus paving the way for a freer flow of people and goods across the border. Military cooperation has also grown with the sale to China of Russian military equipment /9/. Finally, SinoRussian economic cooperation and trade have increased. According to the Mainichi Shimbun, in 1993 Sino-Russian trade amounted to US \$7 billion, far greater than even in the late 1950s. In the near future, the two countries, because of domestic priorities, will continue to develop their relations on the basis of the five principles of peaceful coexistence, and both nations might possibly look for Western aid and assislance/10/.

As far as Indochina and North Korea are concerned, after the Soviet collapse there developed between China and these countries a special kind of solidarity because of their shared desire to defend a one-party system and socialism. Chinese solidarity is especially obvious with North Korea where, for example, just recently China rebuffed a request to join the other four permanent members of the Security Council in forcing North Korea to allow international nuclear inspections.

China has made special efforts to cultivate friendly relations with Japan. There are forecasts of increasing economic rivalry and competing nationalism but at present relations between the two countries are the best they have been since the mid-nineteenth century/11/. China and India have already agreed to promote stability along one of the longest borders in the world. Measures agreed upon include parity of border forces, transparency in troop movements, a nonaggression clause and acceptance of the line of actual control. It should be noted that these measures were taken without disturbing the close ties between China and Pakistan. China's de facto two-Korea policy has became a de jury policy. Relations with the six ASEAN states are better than ever, with diplomatic ties reestablished with Indonesia and Brunei. China also quickly recognized and established diplomatic relations with the five newly independent Central Asian states.

On the whole, one might say that tension and confrontation have been replaced by increased economic cooperation, visits by leaders, and a variety of confidence-building measures conducive to regional stability. China's relations with all of its neighbors have never been freer from distrust.

Beyond China's neighbors, however, the horizon is cloudy. China has its troubled relations with the sole remaining global power, the United States. Chinese leaders consider the United States a subversive force, especially for their younger generation. Sino-American relations are also troubled by issues of trade, intellectual property, prison-made goods, Chinese sales of strategic weap- 
ons, and human rights. Those controversies with the United Slates are likely to grow, judging by statements made by President Clinton and his Secretary of State.

Although China has shown a willingness to discuss a wide range of issues, many countries remain dissatisfied with Beijing's level of cooperation on the topics just mentioned and also with its recent interest in power-projecting sys-tems such as in-flight aircraft-refueling technology and aircraft carriers, as well as its attitude on the future of Hong Kong, and the Sparely, Parcel and Sneak islands. A still more difficult question concerns Taiwan. Will Taiwan seek independence? Or will it become part of China? China's leaders have stated clearly that they would "teach a lesson", using military force if Taiwan should decide to declare itself independent. Many scholars and politicians, however, agree Thai Taiwanese de facto independence must be maintained due to the incompatibility of positions of the two sides/12/.

What worries many countries the most is that the China of tomorrow, having acquired the attributes of a superpower, will act like one. Whether China will become assertive or even aggressive will depend on China's capabilities, mainly economic, on its external setting, and on its international legal obligations which I will try to elaborate on next.

\section{Constraints on Chinese Foreign Policy}

\section{Realpolitik and China}

Since the Treaty of Westphalia international relations have had many theories, but it was between the two world wars that a contemporary theory on international relations emerged. First appeared The Twenty Years of Crises, a pioneering work in the theory of modern international relations by H.F.Carr. Followed by Politics among Nations by Hans Morgenthau. Karl Deutsch and others. All of them had in mind one single idea: the theoretical foundations of realpolitik. The basic idea of political realism is the national interest, defined in terms of power. Political realism is first of all power politics Morgenthau once said that the United Status's foreign policy has only one guiding star, the national interest. A British statesman was quoted as saying that Britain had no eternal friends nor perpetual enemies, but eternal interests. For realpolitik. World politics is a perpetual struggle for power and survival. "The strong do what they can and the weak suffer what the $\backslash$ must" is the favorite slogan of political realists. 
Will China accept this kind of realpolitik? The immediate answer is probably not which explains the quarrels in present Sino-Amcrican relations. China feels that the United States is pursuing a kind of realpolitik toward China. Realpolitik is the politics of power which China lacks at present. Although its economy is becoming stronger. China is still a developing nation.In this sense China cannot be compared with the United States. Japan or Gerniany.lt is also true that its military budget is increasing, but China is not yet a military superpower capable of deploying military forces far from its borders, as the United States and Russia can. Besides, such deployment would worry China's neighbors enormously which. In turn, would hurt China's domestic reforms, which are presumably its top national priority. China might flex its muscles in disputes over the Sparely islands or the Sneak islands or Taiwan, but it would do so merely to divert domestic attention from some unpopular domestic policies.

\section{China's Increasing Interdependence with the Outside World}

To a large extent economics is in charge of world politics at present. The capacity of the scientific-technological revolution to produce rapid and dramatic improvements in human livelihood and economies directly affects a country's capacity to influence international relations. At the same time, no nation has the ability to produce all goods and services necessary for its citizens which leads to economic interdependence and integration. Members of the European Union have become more integrated, as have the United States and Japan. Networks of trade and investment reflecting world market forces as well as national policies have become the sinews of integration

In China's case it is still too early to talk about integration, but one could talk about an emerging interdependence with surrounding countries. By 1978 problems in China's economy, which had been largely shut off from the Western socialist countries as well as the market economies, became apparent to the leadership which then launched at the third plenum of the eleventh Chinese Communist Party central committee in December 1978 the now well-known economic reforms.Foreign capital and technology were invited to special economic zones of which the most famous was Shenzhen, across the border from Hong Kong. Soon China's trade began to grow. The 1990 total of US \$ 115.4 billion represented nearly a six-fold increase over 1978. Indeed, some observers felt that China's economy had become too dependent upon exports.

In this connection, a phenomenon that Robert Scaloppini call natural economic territories is emerging between Guangdong. HongKong, and Taiwan, and also between Fujian and Taiwan. Cutting across political boundaries. South- 
west China has begun to look seriously at Southeast Asia. Meanwhile, China's northeastern provinces are trying to develop closer economic ties with Japan and Korea. The northern provinces of China also are shifting toward developing bilateral as well as multilateral ties with the Russian Far East, Mongolia and, in the case of Xinjiang, with Kazakhstan and other Central Asian republics. In other words, virtually all important parts of China are forming closer economic ties with neighboring states.

During the Gorbachev era, active economic cooperation began between China and the Soviet Far East that included an exchange of people, border trade and joint ventures. In 1985. 65\% of Soviet Far Eastern exports still went to Japan and only $10 \%$ to China, but by 1992 Japan's share dropped to $47.2 \%$ and China's rose to $29.5 \%$. As the figures show, the collapse of the USSR came at time when Soviet trade with Japan declared and trade with China increased.

To a certain extent China's reform efforts are shilling from the South to the North, particularly Inner Mongolia, the Northeast and Xinjiang, thereby revealing China's geopolitical interests. China is participating in the UNDP-sponsored Tumen River project which could help China's Northeast. Recently China has become Mongolia's second most important trading partner. Given the political and economic instability in Russia and economic reforms underway both in Mongolia and China, Sino-Mongolian economic ties and trade have been increasing so rapidly that some people are worried that Mongolia might become too dependent on China.

China is also stepping up economic cooperation with Central Asia. During Kazakhstan's President Nazarbaev's visit to China last year, he discussed a number of projects, including the construction of a trans-Asia railway, a gas pipeline and an economic zone along their common frontier. China's leaders evidently think that greater economic cooperation is the best way to ease such dangerous problems as ethnic upheavals and religious confrontations in China's border areas. As long as the leadership sees practical benefits from such cooperation, it is unlikely to resort to an aggressive policy.

In addition to closer cooperation with its neighbors, China is pursuing the same goal through participation in regional economic organizations like APEC. PECC and ADB and in global organizations like the International Monetary Fund and the World Bank. China is also eager to retake its place in GATT and probably will be accepted soon $/ 15 /$.

\section{China and the Observance of International Law}

One of the most important development in international law during the twentieth century has been the expanded role played by multilateral treaties. 
They often clarify and improve the rules of international law through their binding written agreements. These treaties ales tend to promote uniform behavior by participating states in a variety of fields. Without that kind of treaty, some recalcitrant state could act, like Iraq today, as a spoiler for the entire international community. International organizations, themselves the creatures of multilateral treaties, have also assumed increasing prominence in the last half of this century. They contribute to the coordination and facilitation of contemporary international relations on the basis of legal principles. Nevertheless, international law in general and multilateral organizations in particular often failed in this regard during the cold war when not law but two contending ideologies decided international problems.

The end of the cold war has offered international law new opportunities as well as new challenges. In the new circumstances, the importance of multilateral governmental and non-governmental organizations and particularly that of the United Nations is immensely enhanced. The UN Secretary-General Boutros Boutros-Ghali declared that "the cold war being over, the UN could play the pivotal role in establishing world order and progress that had been assigned to it by the drafters of the Charter".

China is a Security Council member, with special obligations in preserving world peace and security. Two points deserve our attention. First, right after the end of the cold war a number of international crises and even wars broke out, constituting a real test for Chinese diplomacy. China voted in favor of all Security Council resolutions: on Iraqi aggression against Kuwait, the Yugoslav crises, the Cambodian peace-keeping operations, and the Somali events. The only issue on which China has been reluctant is the IAA's inspections of North Korean nuclear plants. Thus, China's position in the United Nations and its actions have mostly been in line with those of other permanent members of the Security Council. Second, China's often proclaimed "five principles of peaceful coexistence" were, in reality, not created by China in a trade agreement with India in 1954, but had already been included in the Charter of the United Nations in 1945 .

Today the United Nations may be criticized in terms of its organizations, Security Council membership and other issues, but few states would challenge the Charter's basic principles, because violating them would mean political, economic, and even military sanctions from the international community. The Chinese have drawn hard lessons from the Tiananmen killings, and it is difficult to believe that they will shed blood beyond their borders in which case the international reaction could be much harsher. 


\section{Conclusion}

China's top priority at present is the economy. Its leaders seem prepared to continue the reforms, but worries about inflation, an overheating economy and unrest among farmers and industrial workers are casting a shadow over reforms.

China's economy will decisively influence its political situation. A healthy economy will strengthen political stability but a runaway economy would lead to instability. Besides the economy there are several other factors that may upset political stability, the most alarming being the coming leadership change. A Soviet-style split of the country' is, however, unlikely given the differences between the two societies. If the present trend of China's politics remains unchanged, Chinese society will in a few years become more similar to Taiwanese or South Korean societies. Internationally, after the collapse of the USSR, China found itself virtually without an enemy. This favorable environment offered the country a golden opportunity to pay more attention to domestic issues. Changes in China's attitude led to changes in its foreign policy priorities and goals. China's foreign policy is becoming more oriented toward Asia than the Third World, and its observance of the "five principles of peaceful coexistence" has changed from dogmatic to pragmatic.

It is unlikely that China will adopt an aggressive foreign policy in the near future. China needs peace in order to pursue its economic reforms and. in any case, would not be strong enough to pursue such a policy. China's growing economic interdependence with its neighbors and its regional and global interactions will place additional constraints on aggressive behavior, as will the existing international legal system and the bilateral, regional and global legal obligations, assumed by China as a member of the international community.

Let us hope that these changes will lead more to new opportunities rather than old mistrust in our region and beyond.

\section{NOTES}

1. Nicholas D. Kristof, “The rise of China," Foreign Affairs 72:5 (1993), 74.

2. A good analysis of China's economic situation may be seen in Vikkain Klianna, "China hopes 94 will be key to breaking economic boom-bust cycle". Japan Times. January 27, 1994.

3. Ibid.

4. Peter Ferdinand, "Russian and Soviet shadows over China's future?" International Affairs 68:2 (1992). 379-392 
5. Herald Tribune. February 11, 1994.

6. Li Peng. "Papers on the outline", FBIS-CH1. June 14. 1991, 1 -24.

7. Keimi Hieyeon and Joel R.Campbell, "The price of change: policy reform and leadership transitions in post-1978 Chinese politics with comparison to Gorbachev's Soviet Union." The Journal of East Asian Affairs 8:1(1994). 174.

8. Time Magazine, for example, in a recent issue claimed that there are still 300,000 political prisoners.

9. "The global amis market," The Asian Wall Street Journal, January 28-29. 1994.

10. For example, in the new Russian foreign policy concept China is considered as "first priority in Asia." See Diplomatik Vestnik, October 1992.

11. China-Japan trade in 1993 increased by 31\%o (S3S billion). makingChina Japan's second largest trading partner alter the United States. See Mainichi Shimbun, January 26, 1994.

12. A penetrating analysis can be seen in Ralph Clougli. "The emerging new international legal order in the Western Pacific: the status of Taiwan." The Journal of East Asian .Affairs

13. Robert A. Scalapino. The Last Leninists: The Uncertain Future of Asia's Communist States. 20.

14. Michel J. Rradshaw, "Russian Far East: economic relations with the AsianPacific states." report presented to JIIA-RIIA joint conference in Tokyo. January 1994.

15. Mainichi Shimbun. December 14, 1993. 